\title{
Distinct serum anti-A $\beta$ antibody patterns in hemorrhagic and inflammatory cerebral amyloid angiopathy manifestations
}

Yannick Chantran, PharmD ${ }^{1,2}$, Jean Capron, MD ${ }^{1,3}$, Diana Doukhi, MD ${ }^{1}$, Johanna Felix ${ }^{1}$, Mélanie Féroul $^{1}$, Florian Kruse ${ }^{1}$, Thomas Chaigneau ${ }^{1}$, Guillaume Dorothée, $\mathrm{PhD}^{1}$, Thibault Allou, $\mathrm{MD}^{4}$, Xavier Ayrignac, MD, ${ }^{5}$ Zina Barrou, MD, ${ }^{6}$ Thomas de Broucker, MD, ${ }^{7}$ Corina Cret,MD, ${ }^{8}$ Guillaume Turc, MD, PhD, ${ }^{9}$ Roxane Peres, MD, ${ }^{10}$ Anne Wacongne, MD, ${ }^{11}$ Marie Sarazin, MD PhD, ${ }^{12}$ Dimitri Renard, MD ${ }^{11}$ Charlotte Cordonnier, MD PhD,${ }^{13}$ Sonia Alamowitch, MD PhD ${ }^{1,3}$, Pierre Aucouturier, $\mathrm{MD} \mathrm{PhD}^{1,2} *$

${ }^{1}$ UMRS 938, Hôpital St-Antoine, Sorbonne Université, Inserm, Paris, France

${ }^{2}$ Département d’Immunologie Biologique, Hôpital Saint-Antoine, AP-HP, Paris, France

${ }^{3}$ Service de Neurologie et d'Urgences Neurovasculaires, Hôpital Saint-Antoine, AP-HP, Paris, France

${ }^{4}$ Service de Neurologie, CH Perpignan, Perpignan, France

${ }^{5}$ Service de Neurologie, CHU Montpellier, Hôpital Guy de Chauliac, Montpellier, France

${ }^{6}$ Service de Gériatrie, Hôpital Pitié Salpêtrière, AP-HP, Paris, France

${ }^{7}$ Service de Neurologie, Centre Hospitalier de Saint-Denis, Saint-Denis, France

${ }^{8}$ Service de Neurologie, Centre Hospitalier de Meaux, Meaux, France

${ }^{9}$ Service de Neurologie, GHU Paris Psychiatrie et Neurosciences, Université de Paris, INSERM U1266, FHU NeuroVasc, Paris, France

${ }^{10}$ Service de Neurologie, Hôpital Lariboisière, AP-HP, Paris, France

${ }^{11}$ Service de Neurologie, CHU Nîmes, Hôpital Caremeau, Nîmes, France

${ }^{12}$ Service de Neurologie de la Mémoire et du Langage, Centre Hospitalier Sainte-Anne, Université Sorbonne Paris Cité, Paris, France

${ }^{13}$ U1172 - LilNCog - Lille Neuroscience \& Cognition, Inserm, CHU Lille, Univ. Lille, Lille, France 
medRxiv preprint doi: https://doi.org/10.1101/2020.10.07.20208330; this version posted October 9, 2020. The copyright holder for this preprint (which was not certified by peer review) is the author/funder, who has granted medRxiv a license to display the preprint in perpetuity.

All rights reserved. No reuse allowed without permission.

\section{* Correspondence:}

Pierre Aucouturier

pierre.aucouturier@inserm.fr

Keywords: anti-A $\beta$ antibodies, natural antibodies, cerebral amyloid angiopathy, stroke, $\mathrm{A} \beta$ related angiitis.

Study funding : supported by the SATT Lutech 
medRxiv preprint doi: https://doi.org/10.1101/2020.10.07.20208330; this version posted October 9, 2020. The copyright holder for this preprint (which was not certified by peer review) is the author/funder, who has granted medRxiv a license to display the preprint in perpetuity.

All rights reserved. No reuse allowed without permission.

\section{Abstract}

Objective: To study blood anti-A $\beta$ antibodies in the context of spontaneous inflammatory or hemorrhagic CAA manifestations, which are similar to complications occurring after monoclonal anti-A $\beta$ antibody immunotherapies.

Methods: In this case-control study, serum anti-A $\beta$ antibody isotype, concentration, avidity, and reactivity toward soluble or fibrillary $A \beta_{1-40}$ and $A \beta_{1-42}$ isoforms were assessed using an ELISAbased multiplex analysis. Anti-A $\beta$ serologic patterns were defined in CAA and CAA subgroups using multivariable logistic regression analyses.

Results: Fourty-one healthy aged controls and 64 CAA patients were recruited: 46 with hemorrhagic features (CAA-he) and 18 with CAA-related inflammation (CAA-ri). As compared to controls, the most striking features of CAA-related serological profiles were the following: i) both CAA-he and CAA-ri patients displayed lower binding diversity of anti-soluble $\mathrm{A} \beta_{1-40} \operatorname{IgM}$; ii) CAA-he patients displayed higher anti-soluble $A \beta_{1-40} /$ fibrillary $A \beta_{1-42}$ IgG4 concentrations ratio and higher antisoluble $A \beta_{1-42}$ IgG4 and IgA avidity; iii) CAA-ri patients displayed higher binding diversity of antisoluble $A \beta_{1-40}$ IgG3 and higher anti-fibrillary/soluble $A \beta_{1-42}$ IgG4 dilution curve steepness ratio.

Conclusion: This proof-of-concept study revealed anti-A $\beta$ antibody variations in CAA patients, some of which were associated to CAA clinical phenotypes, unveiling pathophysiological insights regarding CAA-hemorrhagic and inflammatory related events. 
medRxiv preprint doi: https://doi.org/10.1101/2020.10.07.20208330; this version posted October 9, 2020. The copyright holder for this preprint (which was not certified by peer review) is the author/funder, who has granted medRxiv a license to display the preprint in perpetuity.

All rights reserved. No reuse allowed without permission.

\section{Introduction}

Cerebral amyloid angiopathy (CAA) relates to cortical and leptomeningeal vessel microangiopathy with accumulation of vascular amyloid fibrils made of amyloid- $\beta$ peptide $(\mathrm{A} \beta) .{ }^{1} \mathrm{CAA}$ is frequent in both Alzheimer's disease (AD) and non-AD aged participants. Intracerebral hemorrhage (ICH) related to CAA (CAA-he) is a major health concern. ${ }^{2}$ CAA-related inflammation (CAA-ri) is a rare but treatable $\mathrm{A} \beta$-related CNS vasculitis. ${ }^{3}$

Dose-dependent adverse events similar to CAA-he and CAA-ri were observed upon anti-A $\beta$ immunotherapy in $\mathrm{AD},{ }^{4}$ suggesting a role of anti-A $\beta$ antibodies in CAA manifestations. Subsequent investigations revealed elevated CSF levels of anti-A $\beta$ IgG during CAA-ri. ${ }^{5,6}$ However, it was shown experimentally that blood-borne more than CSF-borne anti-A $\beta$ antibodies can aggravate CAA manifestations in mouse models. ${ }^{7,8}$

As well as other auto-antibodies involved in neurodegenerative disorders, including anti-Tau protein ${ }^{9}$ and anti-alpha synuclein antibodies, ${ }^{10}$ anti-A $\beta$ antibodies belonging to the "natural" auto-antibody repertoire: they are present in both diseased and healthy individuals, displaying low-avidity and multi-reactivity, and circulating mostly as immune complexes. ${ }^{11}$ These complexes require dissociation prior to analysis, in order to reveal serological specificities in AD. ${ }^{11,12}$ These features have likely hindered consistent analyses regarding anti-A $\beta$ antibodies, which was also the case for anti-alpha synuclein antibodies. ${ }^{10}$ In $\mathrm{AD}$, anti-A $\beta$ antibodies measurement led to inconsistent conclusions. ${ }^{11-14}$ Circulating anti-A $\beta$ antibodies were scarcely studied in CAA.

Our working hypothesis was that CAA and related clinical manifestations would relate to particular characteristics of serum anti-A $\beta$ antibodies, including concentration, avidity, specific reactivity towards $A \beta$ isoforms, and class and subclass diversity. 
medRxiv preprint doi: https://doi.org/10.1101/2020.10.07.20208330; this version posted October 9, 2020. The copyright holder for this preprint (which was not certified by peer review) is the author/funder, who has granted medRxiv a license to display the preprint in perpetuity.

\section{Materials and methods}

\section{Study design and participants}

This case-control study enrolled participants from Jan. 2013 to Jun. 2019, through nine French medical centers: CAA patients, and healthy aged controls lacking clinical and MRI features of CAA. Patients with CAA were classified into: CAA-he inpatients with probable or definite CAA according to the modified Boston criteria; ${ }^{15,16}$ CAA-ri inpatients fulfilling the criteria for non-invasive diagnosis of CAA-ri. ${ }^{17}$ Demographics, medical history, and cerebral MRI were recorded at admission.

For the control group, inclusion criteria were: age > 55 years; recent MRI with normal diffusion sequences (transient ischemic stroke, functional neurological symptoms, or symptoms of peripheral origin); exclusion criteria were: cognitive decline (short Informant Questionnaire on Cognitive Decline in the Elderly (IQCODE-R) > 3.4); MRI-proven lobar ICH, recent ischemic stroke, or Fazekas grading $\geq 2$ for white matter hyperintensities.

All eligible patients who gave their consent to participate in the study were included. All serum aliquots were kept at $-20^{\circ} \mathrm{C}$ until use, with a median storage duration of 19 (3-42), 16 (3-50), and 27 (4-55) months (range) for the control, CAA-he, and CAA-ri groups, respectively.

\section{Standard Protocol Approvals, Registrations, and Patient Consents}

The study protocol was approved by the ethics committee "Paris Ile de France V". All participants representative were provided oral and written information, and gave oral or written consent to participate.

\section{Imaging assessment}


medRxiv preprint doi: https://doi.org/10.1101/2020.10.07.20208330; this version posted October 9, 2020. The copyright holder for this preprint (which was not certified by peer review) is the author/funder, who has granted medRxiv a license to display the preprint in perpetuity.

All rights reserved. No reuse allowed without permission.

Diagnoses were adjudicated by one board-certified neurologist (JC) specialized in stroke, blind to biological information. Cerebral lobar microhemorrhages were defined as small round foci of hypointense signal in T2*-GRE-weighted images, $10 \mathrm{~mm}$ or less in brain parenchyma and rated according to the microhemorrhages anatomical rating scale. ${ }^{18}$ Cortical superficial siderosis (cSS) was assessed according to the cSS multifocality scale. ${ }^{19}$

\section{A $\beta$ preparations}

Synthetic $(>95 \%) A \beta_{1-40}$ and $A \beta_{1-42}$ peptides (Proteogenix, Schiltigheim, France) were dissolved in hexafluoroisopropanol, and $450 \mu \mathrm{g}$ aliquots were evaporated in low retention tubes and stored at -20 ${ }^{\circ} \mathrm{C}$ until use. Before use, lyophilized $\mathrm{A} \beta$ was dissolved in $10 \mu \mathrm{L}$ dimethylsulfoxide (DMSO), sonicated for $3 \mathrm{~min}$ at 300 Watts. For soluble preparations, aliquots were then mixed with $90 \mu \mathrm{L}$ $30 \mathrm{mM}$ HEPES 10eq $\mathrm{Cu}^{2+} \mathrm{pH} 7.4$ buffer with $10 \mathrm{mM}$ or $160 \mathrm{mM} \mathrm{NaCl}$ for $\mathrm{A} \beta_{1-42}$ and $\mathrm{A} \beta_{1-40}$, respectively. For fibril preparations, aliquots were then mixed with $90 \mu \mathrm{L} 0.01 \mathrm{~N} \mathrm{HCl}$ or $\mathrm{A} \beta_{1-40}$ coating buffer, incubated at $37^{\circ} \mathrm{C}$ during $72 \mathrm{~h}$ or 15 days, for $\mathrm{A} \beta_{1-42}$ and $\mathrm{A} \beta_{1-40}$, respectively.

\section{Multiplex ELISA for anti-A $\beta$ antibody analyses}

Freshly prepared soluble or fibrillar $A \beta_{1-40}$ and $A \beta_{1-42}$ (hereafter termed s-A $\beta_{40}$, s- $A \beta_{42}, f-A \beta_{40}$ or f$\mathrm{A} \beta_{42}$ ) were diluted to $15 \mu \mathrm{g} / \mathrm{mL}$ in coating buffer (30mM HEPES $160 \mathrm{mM}$ or $10 \mathrm{mM} \mathrm{NaCl}$ (for $\mathrm{A} \beta_{1-40}$ and $\mathrm{A} \beta_{1-42}$, respectively) $10 \mathrm{eq} \mathrm{Cu}^{2+}$ (for monomers) $\mathrm{pH} 7.4$ ), distributed at $100 \mu \mathrm{L}$ per well into ELISA plates (Greiner BioOne) and incubated 16 hours at $4^{\circ} \mathrm{C}$. Serial dilutions of serum samples at 1:50 to $1: 12800$ in $0.1 \mathrm{M}$ Glycine- $\mathrm{HCl}$ buffer $\mathrm{pH} 3.0$, were left 40 minutes at $20^{\circ} \mathrm{C}$ for dissociation of immune complexes, neutralized to $\mathrm{pH} 7.4$ by adding the same volume of $2 x \mathrm{PBS} 4 \%$ BSA $0.02 \mathrm{~N}$ $\mathrm{NaOH}$, then $100 \mu \mathrm{L}$ were immediately deposited into s-A $\beta_{40}$, s- $\mathrm{A} \beta_{42}, \mathrm{f}-\mathrm{A} \beta_{40}$ or $\mathrm{f}-\mathrm{A} \beta_{42}$-coated ELISA plates and incubated $1 \mathrm{~h}$ at $20^{\circ} \mathrm{C}$. After eight washes with PBS $0.05 \%$ Tween-20, bound antibodies of each IgG subclass were detected by $16 \mathrm{~h}$ incubation at $4^{\circ} \mathrm{C}$ of monoclonal anti-human $\operatorname{IgG} 1, \operatorname{IgG} 2$, 
medRxiv preprint doi: https://doi.org/10.1101/2020.10.07.20208330; this version posted October 9, 2020. The copyright holder for this preprint (which was not certified by peer review) is the author/funder, who has granted medRxiv a license to display the preprint in perpetuity.

All rights reserved. No reuse allowed without permission.

IgG3, or IgG4 antibodies (clones NL16, GOM2, ZG4 and RJ4, respectively). After eight washes with PBS $0.05 \%$ Tween-20, antibodies belonging to $\mathrm{IgG}$, IgA and IgM classes and IgG subclasses were revealed after $1 \mathrm{~h}$ incubation at $20^{\circ} \mathrm{C}$ with peroxidase-conjugated antisera (anti-mouse $\operatorname{IgG}$ for $\mathrm{IgG}$ subclasses, or anti-human $\operatorname{IgG}, \operatorname{IgA}$, and $\operatorname{IgM}, 1: 5000$ in washing buffer, Jackson ImmunoResearch Inc.). Washed plates were revealed with $\mathrm{H}_{2} \mathrm{O}_{2} / \mathrm{o}$-phenylene-diamine substrate in $0.15 \mathrm{M}$ urea buffer $\mathrm{pH} 5.0$, the reaction stopped with $2 \mathrm{~N} \mathrm{H}_{2} \mathrm{SO}_{4}$, and optical densities (OD) measured at $492 \mathrm{~nm}$. Nonspecific signals obtained in uncoated wells were subtracted from overall signals retain OD relating to specific anti-A $\beta$ binding. Of note, IgG2 antibodies yielded low binding to $\mathrm{A} \beta$ and unusable dilution curves as previously found in $33 \mathrm{AD}$ and controls. ${ }^{12}$

\section{Quality management of multiplex ELISA}

Samples were randomized and analyzed blindly to minimize bias due to manipulator and inter-assay variability. Randomization was stratified in order to include samples from all clinical groups, so any experimental bias would affect all groups comparably. Pools of human sera were used as internal standard for inter-experiment normalization, and internal control to assess inter-assay variability. Results over 2.5 standard deviation (sd) for one curve parameter were considered invalid.

\section{Determination of dilution curve parameters}

Serum serial dilution curves follow a sigmoid-shaped signal in semi-logarithmic units, as illustrated on Fig $1 \mathrm{~A} .{ }^{20}$ The best fitting sigmoid curve parameters were determined by non-linear least square approach, following the equation:

$$
\text { specific } O D=\frac{a}{1+b \cdot e^{-c \cdot x}}
$$

The values of $a, b$, and $c$ directly relate to sigmoid curve parameters, hence to antibody properties. Maximum (a) signal obtained in antibody excess relate to the number of antigen binding sites, hence 
medRxiv preprint doi: https://doi.org/10.1101/2020.10.07.20208330; this version posted October 9, 2020. The copyright holder for this preprint (which was not certified by peer review) is the author/funder, who has granted medRxiv a license to display the preprint in perpetuity.

All rights reserved. No reuse allowed without permission.

on the diversity of epitope recognition by polyclonal anti-A $\beta$ antibodies. Titer $(\ln (b) / c)$ reflects the $\mathrm{x}-$ axis position of the curve, and depends on both concentration and avidity of the antibodies. The Steepness or Slope of the curve at the inflexion point $(-c / 4 a)$ can vary with cooperativity phenomena occurring between distinct antibody binding sites. The apparent Avidity constant was calculated through a linearization procedure of the sigmoid curve (Fig 1B). ${ }^{21}$ In order to ensure appropriate goodness-of-fit of experimental data, only curves with $\mathrm{R}>0.9$ were taken into account.

\section{Statistical analysis}

For each individual, 96 serological variables were analyzed (Maximum, Titer, Steepness and Avidity for anti-soluble and fibrillar $\mathrm{A} \beta 40$ and $\mathrm{A} \beta 42 \mathrm{IgG}$, IgA, IgM, IgG1, IgG3, and IgG4). In order to limit multiple comparison bias, we chose not to perform univariate analysis. Multiple logistic regression models were computed using stepwise variable selection. The criteria for retaining a variable into the model were that all variables were significantly associated with the risk of belonging to the diseased group (tested by the Wald's test; $\mathrm{p}<0.05$ ) and that introducing this variable allowed a significant improvement of the model against the (k-1) model, as measured by a significant drop of the residual variance (tested by a Likelihood Ratio test; p-value < 0.05). Variance Inflation Factors (VIFs) were computed for each final model to ensure the absence of collinearity between variables. A VIF value of 1 is obtained when there is no collinearity between variables, while a VIF value $>5$ witnesses high multicollinearity in the model. Wilcoxon's test was used to compare the predicted response of the models between clinical groups. All statistical analyses were done with R version 3.6.1. The MASS package was used for model selection, and the beeswarm package for plots.

\section{Data Availability Statement}

Data are available upon reasonable request. 
medRxiv preprint doi: https://doi.org/10.1101/2020.10.07.20208330; this version posted October 9, 2020. The copyright holder for this preprint (which was not certified by peer review) is the author/funder, who has granted medRxiv a license to display the preprint in perpetuity.

All rights reserved. No reuse allowed without permission.

\section{Results}

\section{Patient demographics and clinico-radiological data}

The study enrolled 105 participants: 41 healthy aged controls, 46 CAA-he patients, and 18 CAA-ri patients. Of note, eight patients from the CAA-he group had cSS but no ICH ; their symptoms were : isolated cognitive decline in 3, transient focal episodes in 4 (2 with acute subarachnoidal hemorrhage); asymptomatic in one. Median (range) ages were 72 (55-89), 79 (59-90), 75 (64-87) years old in the control, CAA-he and CAA-ri groups, respectively. Male/Female ratios were 22/18, 24/21, and 8/9 in the control, CAA-he and CAA-ri groups, respectively. The main clinical and imaging findings in CAA-he and CAA-ri patients are presented in Table I.

\section{Quality assessment of the multiplex ELISA}

The sigmoid modeling of experimental dilution curves showed excellent overall goodness-of-fit (mean $\mathrm{R}^{2}=0.97$; range stratified by antigen isoform: [0.97-0.98]; range stratified by antibody isotype: [0.95-0.99]). This confirmed that experimental dilution curves are appropriately described by the sigmoid model. Internal control mean coefficients of variation (CV) were inferior to $20 \%$ for all four parameters of all antibody isotypes and all $\mathrm{A} \beta$ isoforms (mean $\mathrm{CV}: 16 \%, 7 \%, 16 \%$, and $12 \%$, for maxima, titer, steepness, and avidity, respectively). This validated the multiplex ELISA as a reliable and reproducible method for assessing anti-A $\beta$ antibody features.

\section{Serum anti-A $\beta$ antibody patterns associated with CAA}

Table II presents the anti-A $\beta$ serologic parameters associated with CAA against controls. These parameters are those included in the multivariable logistic regression model after stepwise variable selection. Fig $2 \mathrm{~A}$ presents the predicted response resulting from this CAA-model applied to each individual. This predicted response is associated with the probability of presenting CAA or not, and 
medRxiv preprint doi: https://doi.org/10.1101/2020.10.07.20208330; this version posted October 9, 2020. The copyright holder for this preprint (which was not certified by peer review) is the author/funder, who has granted medRxiv a license to display the preprint in perpetuity.

All rights reserved. No reuse allowed without permission.

is modeled using the individual anti-A $\beta$ profile regarding parameters presented in Table 2 . In this complex profile, a higher diversity and concentration of anti-s-A $\beta_{40} \operatorname{IgG} 3$, a higher avidity of anti-s$\mathrm{A} \beta_{40}$ IgG4 and a higher steepness of anti-f-A $\beta_{42}$ IgG4 were associated with an increased probability of belonging to the CAA group. A lower diversity of anti-s-A $\beta_{40}$ IgM, a lower avidity of anti-s-A $\beta_{42}$ $\operatorname{Ig} \mathrm{A}$, and a lower concentration of anti-f-A $\beta_{42}$ IgG1 were also associated with an increased probability of belonging to the CAA group. All these variables, contributed independently to the model, without multicollinearity (all Variance Inflation Factors (VIFs) < 1.8).

The serological anti-A $\beta$ antibody profile associated with CAA-he as compared to healthy aged controls (Table 2 and Fig 2B) also included lower diversity of anti-s-A $\beta_{40} \operatorname{IgM}$ and lower avidity of anti-s-A $\beta_{42}$ IgA. Regarding the IgG4 isotype, CAA-he patients displayed higher concentrations of anti-s-A $\beta_{40}$ IgG4, and lower concentrations and avidity of anti-A $\beta_{42}$ IgG4, respectively. CAA-he patients also displayed lower avidity of anti-f-A $\beta_{42}$ IgG1 as compared with healthy aged controls. Of note, excluding the $8 \mathrm{CAA}$-he patients that presented cSS without $\mathrm{ICH}$ did not change variables present in this model. All these variables and independently contributed to the model, without multicollinearity (all VIFs $<1.3$ ).

As found in the CAA model, CAA-ri patients (Table 2 and Fig 2C) displayed lower diversity of antis-A $\beta_{40} \operatorname{IgM}$, as also found for CAA-he patients, but also a higher diversity of anti- s-A $\beta_{40} \operatorname{IgG} 3$, and a higher steepness of anti-fibrillar $\mathrm{A} \beta_{42}$ IgG4 dilution curve. Conversely, CAA-ri patients displayed a lower steepness of anti- s-A $\beta_{42}$ IgG4 and anti-s-A $\beta_{40}$ IgA. All these variables contributed independently to the model, without multicollinearity (all VIFs $<1.4$ ).

\section{Discussion}

Analyses of blood anti-A $\beta$ antibodies demonstrate complex serological profiles in CAA, displaying distinctive features in CAA-he and CAA-ri patients. This proof-of-concept study suggests: i) 
medRxiv preprint doi: https://doi.org/10.1101/2020.10.07.20208330; this version posted October 9, 2020. The copyright holder for this preprint (which was not certified by peer review) is the author/funder, who has granted medRxiv a license to display the preprint in perpetuity.

All rights reserved. No reuse allowed without permission.

evidence of a link between anti-A $\beta$ antibody responses and CAA; ii) existence of defined circulating anti-A $\beta$ antibody species associated with distinct pathological phenotypes. In brief, clinical manifestations of CAA appear to relate, at least in part, to a biased natural antibody repertoire or abnormal responses to pathological $\mathrm{A} \beta$ peptide. However, at this stage, these serological profiles may not be used as biomarkers.

The causal relevance of these observations remains to be elucidated. Different naturally occurring anti-A $\beta$ repertoires could be susceptibility factors for developing CAA, possibly by interfering with the clearance of cerebral $A \beta$. Cerebrovascular $A \beta$ deposits may also induce anti-A $\beta$ auto-immune responses emerging from the natural antibody repertoire. Finally, such induced anti-A $\beta$ antibody species might enhance CAA and/or trigger hemorrhagic or inflammatory manifestations, as suggested in experimental mouse models. ${ }^{7,8}$

Although this multivariable modeling approach does not allow pathophysiological conclusions about the role of given anti-A $\beta$ species in $\mathrm{CAA}$, it suggests hypotheses and drives attention towards potentially relevant anti-A $\beta$ features. With the notable exception of anti-fibrillar $\mathrm{A} \beta_{1-42} \operatorname{IgG} 4$, all serologic parameters relating to $A \beta_{1-42}$ were lower in CAA. Regarding antibodies reacting with $A \beta_{1 \text { - }}$ 40, our results show preferential developments of IgG3 and IgG4 antibody responses. Interestingly, lower diversity of anti-soluble $\mathrm{A} \beta_{1-40}$ IgM was the only common feature of CAA-he and CAA-ri patients. This could indicate an IgM response preferentially directed toward some particular pathogenic $A \beta_{1-40}$ epitopes in response to $A \beta_{1-40}$ cerebrovascular deposits.

The role of antibody isotypes in anti-A $\beta$ antibodies related CAA manifestations is elusive. In AD patients treated with monoclonal anti-A $\beta$ antibodies, amyloid related imaging abnormalities with vasogenic edema (ARIA-E) or with hemorrhagic features (ARIA-H) were initially reported with antibodies of IgG1 subclass. ${ }^{22-24}$ No ARIA-E but ARIA-H were yet reported in patients receiving 
medRxiv preprint doi: https://doi.org/10.1101/2020.10.07.20208330; this version posted October 9, 2020. The copyright holder for this preprint (which was not certified by peer review) is the author/funder, who has granted medRxiv a license to display the preprint in perpetuity.

All rights reserved. No reuse allowed without permission.

anti-A $\beta$ IgG4 (Crenezumab), ${ }^{25}$ while the existence of both remains uncertain for $\operatorname{IgG} 2$ (Ponezumab $)^{26,27}$ None of the monoclonal anti-A $\beta$ antibodies used in $\mathrm{AD}$ immunotherapy trials was of the IgG3 subclass. Like IgG1, IgG3 antibodies display potent effector functions including complement classical pathway activation and phagocytic and cytotoxic cell activation. IgG3 were thought to be more pathogenic than other $\operatorname{IgG}$ subclasses in anti-neutrophil cytoplasm antibody (ANCA)-associated vasculitis. ${ }^{28}$

Lobar ICH, MH and cSS were also reported in active immunotherapy trial CAD106, designed for eliciting $A \beta$-specific antibodies without T-cell response. Lobar ICH occurred in a patient without anti-A $\beta$ IgG response to CAD106, but his anti-A $\beta$ IgM status was not reported. ${ }^{29}$ It is worth noting that in ANCA-associated vasculitis, the presence of transient but recurrent IgM-ANCA is associated with a higher severity mainly due to acute hemorrhagic pulmonary manifestations. ${ }^{30}$

The main risks factors for CAA are age, coincidental Alzheimer's disease, and ApoE genotypes, with controversy regarding the respective roles of $\varepsilon 2$ and $\varepsilon 4$ alleles. ${ }^{31}$ We accounted for age and cognitive decline by selecting aged healthy controls without cognitive decline, and CAA patients with normal MMSE. One potential limitation is that, due to unavailable material, ApoE genotypes could not be evaluated in this study. However, used diagnostic criteria for CAA-he and CAA-ri are independent of the ApoE genotype. Part of the serologic diversity might relate to ApoE genotypes, since both $\varepsilon 2^{32,33}$ and $\varepsilon 4^{34}$ alleles have been linked to more severe CAA, with vasculopathies and hemorrhagic phenotypes. This question should be addressed in further studies.

In previous studies, serum anti-A $\beta$ antibodies were mostly analyzed in the context of Alzheimer's disease, with various results reported by different authors using distinct methods. ${ }^{12-14}$ Neuropathological CAA is virtually present in all patients with AD pathology. ${ }^{35}$ However, lobar microbleeds evoking CAA are present in only about $20 \%$ AD patients ${ }^{36}$ while lobar ICH and 
medRxiv preprint doi: https://doi.org/10.1101/2020.10.07.20208330; this version posted October 9, 2020. The copyright holder for this preprint (which was not certified by peer review) is the author/funder, who has granted medRxiv a license to display the preprint in perpetuity.

All rights reserved. No reuse allowed without permission.

spontaneous manifestations similar to CAA-ri are rare in AD. This may be explained by the distinct CAA neuropathological phenotypes in $\mathrm{AD}$ and in patients with CAA clinical manifestations. ${ }^{37}$ Whether $\mathrm{AD}$ patients with and without cerebral microbleed would present with different anti-A $\beta$ serological signatures as compared to CAA-he and CAA-ri patients is thus likely and will be addressed in further studies.

Anti-A $\beta$ antibodies circulate mostly as immune complexes, ${ }^{11}$ but whether these complexes include circulating $A \beta$, cross-reactive proteins, and/or anti-idiotype antibodies is not known. As previously performed by others, ${ }^{11-12,38}$ we used acidic dissociation of serum samples followed by extemporaneous neutralization to analyze all circulating anti-A $\beta$ antibodies regardless of their free or bound state. We used high purity synthetic $A \beta$ preparations and appropriate blank controls to ensure binding specificity. Of note, given the low specific signal obtained with non-dissociated samples once the background is subtracted, dilution curve analysis could not have been performed on nondissociated samples. That anti-A $\beta$ antibodies circulate mostly as immune complexes also raises questions regarding plasma $A \beta$ levels measurements. Contradictory results exist on circulating $A \beta$ levels in CAA. ${ }^{39,40}$ The circulating levels of free $\mathrm{A} \beta$ should depend on the concentrations and affinities of circulating anti-A $\beta$ antibodies, and it is possible that the experimental conditions in which $A \beta$ measurements are performed cannot fully circumvent $A \beta$ masking by circulating anti-A $\beta$ antibodies.

In conclusion, this correlative proof-of-concept study demonstrates distinct serum anti-A $\beta$ antibody patterns in CAA and its hemorrhagic and inflammatory manifestations. Larger prospective and experimental studies could elucidate the triggering role of anti-A $\beta$ antibodies in spontaneous or immunotherapy-induced CAA manifestations, and provide appropriate biomarkers. 
medRxiv preprint doi: https://doi.org/10.1101/2020.10.07.20208330; this version posted October 9, 2020. The copyright holder for this preprint (which was not certified by peer review) is the author/funder, who has granted medRxiv a license to display the preprint in perpetuity.

All rights reserved. No reuse allowed without permission.

\section{Acknowledgments}

We thank Dr Margaret Goodall (Birmigham, UK) for providing anti-IgG subclass antibodies.

\section{Author contributions}

Study concept and design: YC, JC, SA, PA. Data acquisition and analysis: YC, JC, DD, JF, MF, FK, TC, TA, XA, ZB, TdB, CC, GT, RP, AW, MS, DR, CC. Drafting the manuscript and figures: YC, JC, GD, CC, SA, PA.

\section{Conflict of interest}

The authors declare that the research was conducted in the absence of any commercial or financial relationships that could be construed as a potential conflict of interest. 
medRxiv preprint doi: https://doi.org/10.1101/2020.10.07.20208330; this version posted October 9, 2020. The copyright holder for this preprint (which was not certified by peer review) is the author/funder, who has granted medRxiv a license to display the preprint in perpetuity.

\section{References}

1. Charidimou A, Boulouis G, Gurol ME, Ayata C, Bacskai BJ, Frosch MP, et al. Emerging concepts in sporadic cerebral amyloid angiopathy. Brain 2017a; 140: 1829-50.

2. Béjot Y, Cordonnier C, Durier J, Aboa-Eboulé C, Rouaud O, Giroud M. Intracerebral haemorrhage profiles are changing: results from the Dijon population-based study. Brain 2013; 136 : 658-64.

3. Salvarani C, Hunder GG, Morris JM, Brown RD Jr, Christianson T, Giannini C. A $\beta$-related angiitis: comparison with CAA without inflammation and primary CNS vasculitis. Neurology 2013; 81: 1596-603.

4. Sperling RA, Jack CR Jr, Black SE, Frosch MP, Greenberg SM, Hyman BT et al. Amyloid-related imaging abnormalities in amyloid-modifying therapeutic trials: recommendations from the Alzheimer's Association Research Roundtable Workgroup. Alzheimers Dement 2011; 7:367-85.

5. Piazza F, Greenberg SM, Savoiardo M, Gardinetti M, Chiapparini L, Raicher I, et al. Anti-amyloid $\beta$ autoantibodies in cerebral amyloid angiopathy-related inflammation: implications for amyloidmodifying therapies. Ann Neurol 2013; 73: 449-58.

6. DiFrancesco JC, Longoni M, Piazza F. Anti-A $\beta$ Autoantibodies in Amyloid Related Imaging Abnormalities (ARIA): Candidate Biomarker for Immunotherapy in Alzheimer's Disease and Cerebral Amyloid Angiopathy. Front Neurol 2015; 6: 207.

7. Pfeifer M, Boncristiano S, Bondolfi L, Stalder A, Deller T, Staufenbiel M et al. Cerebral hemorrhage after passive anti-Abeta immunotherapy. Science. 2002; 298: 1379.

8. Thakker DR, Weatherspoon MR, Harrison J, Keene TE, Lane DS, Kaemmerer WF, et al. Intracerebroventricular amyloid-beta antibodies reduce cerebral amyloid angiopathy and associated micro-hemorrhages in aged Tg2576 mice. Proc Natl Acad Sci USA 2009; 106: 4501-06.

9. Krestova M, Hromadkova L, Ricny J. Purification of Natural Antibodies Against Tau Protein by Affinity Chromatography. Methods Mol Biol 2017; 1643: 33-44.

10. Folke J, Rydbirk R, Løkkegaard A, et al. Distinct Autoimmune Anti- $\alpha$-Synuclein Antibody Patterns in Multiple System Atrophy and Parkinson's Disease. Front Immunol 2019; 10: 2253.

11. Britschgi M, Olin CE, Johns HT, Takeda-Uchimura Y, LeMieux MC, Rufibach K et al. Neuroprotective natural antibodies to assemblies of amyloidogenic peptides decrease with normal aging and advancing Alzheimer's disease. Proc Natl Acad Sci USA. 2009; 106: 12145-50.

12. Dorothée G, Bottlaender M, Moukari E, de Souza LC, Maroy R, Corlier F et al. Distinct patterns of antiamyloid- $\beta$ antibodies in typical and atypical Alzheimer disease. Arch Neurol 2012; 69: 11815.

13. Du Y, Dodel R, Hampel H, Buerger K, Lin S, Eastwood B et al. Reduced levels of amyloid betapeptide antibody in Alzheimer disease. Neurology 2001; 57: 801-5. 
medRxiv preprint doi: https://doi.org/10.1101/2020.10.07.20208330; this version posted October 9, 2020. The copyright holder for this preprint (which was not certified by peer review) is the author/funder, who has granted medRxiv a license to display the preprint in perpetuity. All rights reserved. No reuse allowed without permission.

14. Maftei M, Thurm F, Schnack C, Tumani H, Otto M, Elbert T et al. Increased levels of antigenbound $\beta$-amyloid autoantibodies in serum and cerebrospinal fluid of Alzheimer's disease patients. PLoS One 2013; 8:e68996.

15. Knudsen KA, Rosand J, Karluk D, Greenberg SM. Clinical diagnosis of cerebral amyloid angiopathy: validation of the Boston criteria. Neurology 2001; 56: 537-9.

16. Linn J, Halpin A, Demaerel P, Ruhland J, Giese AD, Dichgans M et al. Prevalence of superficial siderosis in patients with cerebral amyloid angiopathy. Neurology 2010; 74: 1346-50.

17. Auriel E, Charidimou A, Gurol ME, Ni J, Van Etten ES, Martinez-Ramirez S, et al. Validation of Clinicoradiological Criteria for the Diagnosis of Cerebral Amyloid Angiopathy-Related Inflammation. JAMA Neurol 2016; 73: 197-202.

18. Gregoire SM, Chaudhary UJ, Brown MM, Yousry TA, Kallis C, Jäger HR et al. The Microbleed Anatomical Rating Scale (MARS): reliability of a tool to map brain microbleeds. Neurology 2009; 73: 1759-66.

19. Charidimou A, Boulouis G, Roongpiboonsopit D, Auriel E, Pasi M, Haley K et al. Cortical superficial siderosis multifocality in cerebral amyloid angiopathy: A prospective study. Neurology 2017b; 89: 2128-35.

20. Cheung YB, Xu Y, Remarque EJ, Milligan P. Statistical estimation of antibody concentration using multiple dilutions. J Immunol Methods 2015; 417: 115-23.

21. Orosz F, Ovádi J. A simple method for the determination of dissociation constants by displacement ELISA. J Immunol Methods 2002; 270: 155-62.

22. Ostrowitzki S, Deptula D, Thurfjell L, Scheltens P, Barkhof F, Nikolcheva T et al. Mechanism of amyloid removal in patients with Alzheimer disease treated with gantenerumab. Arch Neurol 2012; 69: 198-207.

23. Salloway S, Sperling R, Fox NC, Blennow K, Klunk W, Raskind M et al. Two phase 3 trials of bapineuzumab in mild-to-moderate Alzheimer's disease. N Engl J Med 2014; 370: 322-33.

24. Sevigny J, Chiao $\mathrm{P}$, Bussière $\mathrm{T}$, Weinreb $\mathrm{PH}$, Williams $\mathrm{L}$, Maier $\mathrm{M}$ et al. The antibody aducanumab reduces $A \beta$ plaques in Alzheimer's disease. Nature 2016; 537: 50-6.

25. Cummings JL, Cohen S, van Dyck CH, Brody M, Curtis $\mathrm{C}$, Cho W et al. ABBY: A phase 2 randomized trial of crenezumab in mild to moderate Alzheimer disease. Neurology 2018; 90:e188997.

26. Leurent C, Goodman JA, Zhang Y, He P, Polimeni JR, Gurol ME, et al. Immunotherapy with ponezumab for probable cerebral amyloid angiopathy. Ann Clin Transl Neurol 2019; 6: 795-806.

27. Chantran Y, Capron J, Alamowitch S, Aucouturier P. Anti $\square$ A $\beta$ antibodies and cerebral amyloid angiopathy complications. Front Immunol 2019; 10: 1534.

28. Mulder AH, Stegeman CA, Kallenberg CG. Activation of granulocytes by anti-neutrophil cytoplasmic antibodies (ANCA) in Wegener's granulomatosis: a predominant role for the IgG3 subclass of ANCA. Clin Exp Immunol 1995; 101: 227-32. 
medRxiv preprint doi: https://doi.org/10.1101/2020.10.07.20208330; this version posted October 9, 2020. The copyright holder for this preprint (which was not certified by peer review) is the author/funder, who has granted medRxiv a license to display the preprint in perpetuity. All rights reserved. No reuse allowed without permission.

29. Farlow MR, Andreasen N, Riviere ME, Vostiar I, Vitaliti A, Sovago J, et al. Long-term treatment with active $A \beta$ immunotherapy with CAD106 in mild Alzheimer's disease. Alzheimers Res Ther 2015; 7: 23.

30. Clain JM, Hummel AM, Stone JH, Fervenza FC, Hoffmann GS, Kallenberg CGM, et al. Immunoglobulin (Ig)M antibodies to proteinase 3 in granulomatosis with polyangiitis and microscopic polyangiitis. Clin Exp Immunol 2017; 188: 174-81.

31. Charidimou A, Martinez-Ramirez S, Shoamanesh A, Oliveira-Filho J, Frosch M, Vashkevich A, et al. Cerebral amyloid angiopathy with and without hemorrhage: evidence for different disease phenotypes. Neurology 2015; 84: 1206-12.

32. Nicoll JA, Burnett C, Love S, Graham DI, Dewar D, Ironside JW, et al. High frequency of apolipoprotein E epsilon 2 allele in hemorrhage due to cerebral amyloid angiopathy. Ann Neurol 1997; 41: 716-21.

33. Greenberg SM, Vonsattel JP, Segal AZ, Chiu RI, Clatworthy AE, Liao A, et al. Association of apolipoprotein E epsilon2 and vasculopathy in cerebral amyloid angiopathy. Neurology 1998; 50: 961-5.

34. Alonzo NC, Hyman BT, Rebeck GW, Greenberg SM. Progression of cerebral amyloid angiopathy: accumulation of amyloid-beta40 in affected vessels. J Neuropathol Exp Neurol 1998; 57: 353-9.

35. Jellinger KA, Lauda F, Attems J. Sporadic cerebral amyloid angiopathy is not a frequent cause of spontaneous brain hemorrhage. Eur J Neurol 2007; 14: 923-8.

36. Cordonnier C, van der Flier WM, Sluimer JD, Leys D, Barkhof F, Scheltens P. Prevalence and severity of microbleeds in a memory clinic setting. Neurology 2006; 66: 1356-60.

37. Thal DR, Ghebremedhin E, Rüb U, Yamaguchi H, Del Tredici K, Braak H. Two types of sporadic cerebral amyloid angiopathy. J Neuropathol Exp Neurol 2002; 61: 282-93.

38. Li Q, Gordon M, Cao C, Ugen KE, Morgan D. Improvement of a low pH antigen-antibody dissociation procedure for ELISA measurement of circulating anti-Abeta antibodies. BMC Neurosci 2007; 8: 22.

39. Greenberg SM, Cho HS, O'Donnell HC, Rosand J, Segal AZ, Younkin LH, et al. Plasma betaamyloid peptide, transforming growth factor-beta 1, and risk for cerebral amyloid angiopathy. Ann $\mathrm{N}$ Y Acad Sci. 2000; 903: 144-9.

40. Hernandez-Guillamon M, Delgado P, Penalba A, Rodriguez-Luna D, Molina CA, Rovira A, et al. Plasma $\beta$-amyloid levels in cerebral amyloid angiopathy-associated hemorrhagic stroke. Neurodegener Dis 2012; 10: 320-3. 
medRxiv preprint doi: https://doi.org/10.1101/2020.10.07.20208330; this version posted October 9, 2020. The copyright holder for this preprint (which was not certified by peer review) is the author/funder, who has granted medRxiv a license to display the preprint in perpetuity.

All rights reserved. No reuse allowed without permission.

\section{Figure legends}

\section{Figure 1. Determination of dilution curve parameters by sigmoid modeling and linearization}

procedure. A. Dilution curve obtained from a human serum sample following acidic dissociation of circulating immune complexes and neutralization, incubated on coated soluble $A \beta 1-42$ and revealed with anti-IgG secondary antibody. The dashed thick line represents the sigmoid modeling of the curve, accurately described by i) the y-axis value of the left-sided plateau (Maximum); ii) the x-axis value at the inflexion point (Titer); iii) the slope at the inflexion point (Steepness). B. Linearization of the same experimental points and sigmoid model, which allows the determination of the apparent constant of avidity.

Figure 2. Serological differences associated with CAA clinical phenotypes. A, CAA-model predicted value using the logistic multivariable regression model presented in Table 2, upper part. B, CAA-he model predicted values using the logistic multivariable regression model presented in Table 2, middle part. C, CAA-ri model predicted values using the logistic multivariable regression model presented in Table 2, lower part. *:p<0.05; **: $<<0.01 ; * * *: \mathrm{p}<0.001$. Wilcoxon's test. 
medRxiv preprint doi: https://doi.org/10.1101/2020.10.07.20208330; this version posted October 9, 2020. The copyright holder for this preprint (which was not certified by peer review) is the author/funder, who has granted medRxiv a license to display the preprint in perpetuity.

All rights reserved. No reuse allowed without permission.

Table I. Clinical and radiological characteristics of patients with cerebral amyloid angiopathy

\begin{tabular}{|c|c|}
\hline CAA-ri patients $(n=18)$ & \\
\hline Onset $<1$ month & 8 \\
\hline Symptoms & \\
\hline Cognitive decline & 17 \\
\hline Neurologic deficit & 11 \\
\hline Epilepsy & 6 \\
\hline Headache & 5 \\
\hline Histological diagnosis & 2 \\
\hline MRI findings & \\
\hline Asymetric white matter hypersignal reaching $U$ fibers & 17 \\
\hline Meningeal gadolinium enhancement ( $\mathrm{n}=14$ injected MRIs) & 6 \\
\hline Treatment & \\
\hline Steroid alone & 11 \\
\hline Steroid + Cyclophosphamid & 6 \\
\hline None $^{\mathrm{a}}$ & 3 \\
\hline Outcome $(\mathrm{n}=17)^{\mathrm{b}}$ & \\
\hline Clinical and radiological improvement & 13 \\
\hline Radiological improvement alone & 3 \\
\hline CAA-he patients $(n=46)$ & \\
\hline MRI findings & \\
\hline lobar micro-hemorrhages & 45 \\
\hline cSS score $(0-1-2-3-4)$ & $13 / 15 / 6 / 7 / 5$ \\
\hline Fazekas score (1-2-3) & $9 / 21 / 16$ \\
\hline
\end{tabular}


medRxiv preprint doi: https://doi.org/10.1101/2020.10.07.20208330; this version posted October 9, 2020. The copyright holder for this preprint

(which was not certified by peer review) is the author/funder, who has granted medRxiv a license to display the preprint in perpetuity.

All rights reserved. No reuse allowed without permission.

\begin{tabular}{|l|l|}
\hline Modified Boston criteria for CAA (definite/probable) & $3 / 43$ \\
\hline
\end{tabular}

Abbreviations: CAA, cerebral amyloid angiopathy. CAA-he, cerebral amyloid angiopathy related intracerebral hemorrhage. CAA-ri, cerebral amyloid angiopathy-related inflammation. ICH, intracerebral hemorrhage. cSS, cortical superficial siderosis. a all with clinical and radiological improvement. ${ }^{\mathrm{b}}$ one patient was lost during follow-up 
medRxiv preprint doi: https://doi.org/10.1101/2020.10.07.20208330; this version posted October 9, 2020. The copyright holder for this preprint (which was not certified by peer review) is the author/funder, who has granted medRxiv a license to display the preprint in perpetuity. All rights reserved. No reuse allowed without permission.

Table II. Multivariable logistic regression models for CAA, CAA-he, and CAA-ri against healthy aged controls

\section{CAA model}

Standard Residual

Variables Estimates errors Z-val. P-val. deviances P-val.

\begin{tabular}{|c|c|c|c|c|c|c|}
\hline & 0.13 & 6.57 & & & 140.5 & \\
\hline${ }^{\mathrm{a} A n t i-s-A} \beta_{40}$ IgG3 Maximum & 2.89 & 0.92 & 3.14 & 0.0017 & 134.0 & 0.011 \\
\hline Anti-s-A $\beta_{40}$ IgG3 Titer & 4.03 & 1.16 & 3.48 & 0.0005 & 123.6 & 0.0013 \\
\hline Anti-s-A $\beta_{40}$ IgG4 Avidity & 2.29 & 0.94 & 2.44 & 0.015 & 117.6 & 0.014 \\
\hline${ }^{\mathrm{a}}$ Anti-f-A $\beta_{42}$ IgG4 Steepness & 3.74 & 1.32 & 2.84 & 0.0045 & 111.5 & 0.013 \\
\hline${ }^{\mathrm{b}}$ Anti-s-A $\beta_{40} \operatorname{IgM}$ Maximum & -3.10 & 1.02 & -3.05 & 0.0023 & 102.5 & 0.0027 \\
\hline${ }^{\mathrm{c}}$ Anti-s-A $\beta_{42} \operatorname{Ig} \mathrm{A}$ Avidity & -3.48 & 1.13 & -3.07 & 0.0021 & 92.9 & 0.0019 \\
\hline Anti-f-A $\beta_{42}$ IgG1 Titer & -3.81 & 1.58 & -2.42 & 0.016 & 86.5 & 0.012 \\
\hline
\end{tabular}

CAA-he model

Standard

Residual

Variables

Estimates errors Z-val. P-val. deviances P-val.

42.14

3.30

$-6.41$

$-4.65$

$-2.77$

$-2.09$

$-2.87$
11.84

1.11

1.95

2.04

1.06

1.01

1.24
2.97

0.0030

111.57

0.0031

$-3.29$

0.0010

98.41

0.0003

$-2.28$

0.023

90.72

0.0056

$-2.61 \quad 0.0092$

85.59

0.024

${ }^{\mathrm{b}}$ Anti-s-A $\beta_{40}$ IgM Maximum

Anti-s-A $\beta_{42}$ IgG4 Avidity

$$
-2.06
$$

0.039

80.95

$\begin{array}{lll}-2.32 & 0.020 & 74.92\end{array}$

\section{CAA-ri model}


medRxiv preprint doi: https://doi.org/10.1101/2020.10.07.20208330; this version posted October 9, 2020. The copyright holder for this preprint (which was not certified by peer review) is the author/funder, who has granted medRxiv a license to display the preprint in perpetuity. All rights reserved. No reuse allowed without permission.

\begin{tabular}{|c|c|c|c|c|c|c|}
\hline \multirow[b]{2}{*}{ Variables } & \multicolumn{3}{|c|}{ Standard } & \multicolumn{3}{|c|}{ Residual } \\
\hline & Estimates & errors & Z-val. & P-val. & deviances & P-val. \\
\hline & 10.75 & 5.78 & & & 72.58 & \\
\hline${ }^{\mathrm{a} A n t i-s-A} \beta_{40}$ IgG3 Maximum & 4.15 & 1.55 & 2.68 & 0.007 & 63.92 & 0.0032 \\
\hline${ }^{\mathrm{a} A n t i-f-A} \beta_{42}$ IgG4 Steepness & 4.01 & 1.70 & 2.36 & 0.018 & 58.38 & 0.019 \\
\hline Anti-s-A $\beta_{40}$ IgA Steepness & -18.53 & 8.23 & -2.25 & 0.024 & 54.08 & 0.038 \\
\hline Anti-s-A $\beta_{42}$ IgG4 Steepness & -12.19 & 5.25 & -2.32 & 0.020 & 46.96 & 0.0076 \\
\hline${ }^{\mathrm{b}}$ Anti-s-A $\beta_{40}$ IgM Maximum & -2.40 & 1.21 & -1.99 & 0.047 & 40.68 & 0.012 \\
\hline
\end{tabular}

a: Variables shared between the CAA and the CAA-ri models. ${ }^{\mathrm{b}}$ : Variables shared between the CAA, the CAA-he and the CAA-ri models; ${ }^{c}$ : Variables shared between the CAA and the CAA-he models; 
OD

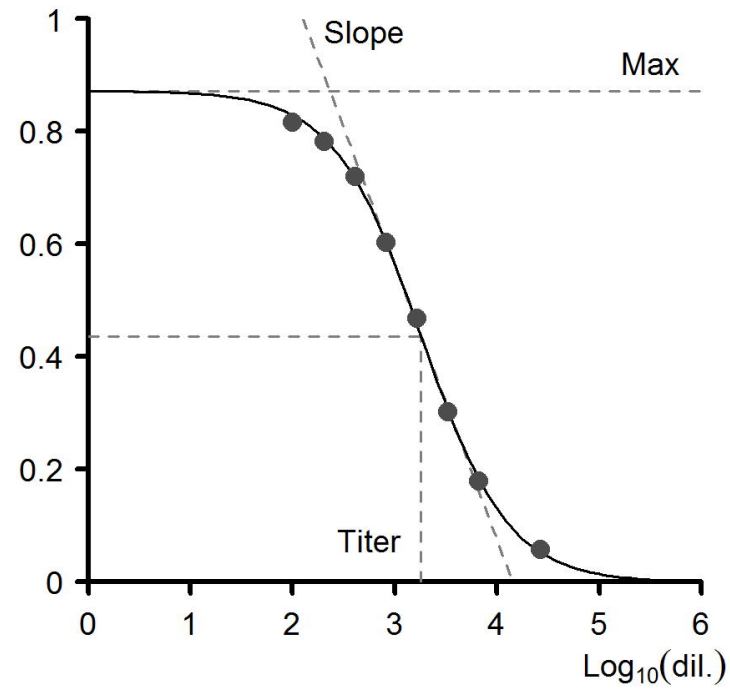

$1 /(1-$ relOD $)$

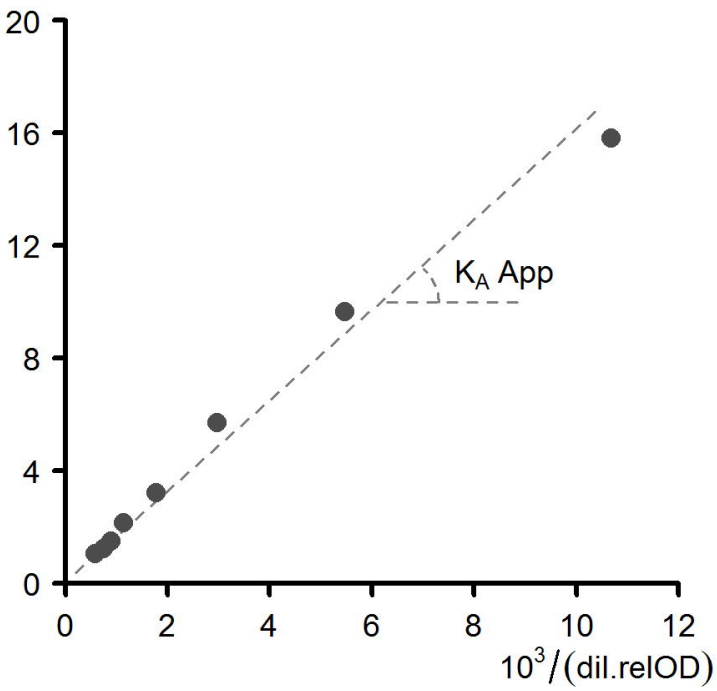



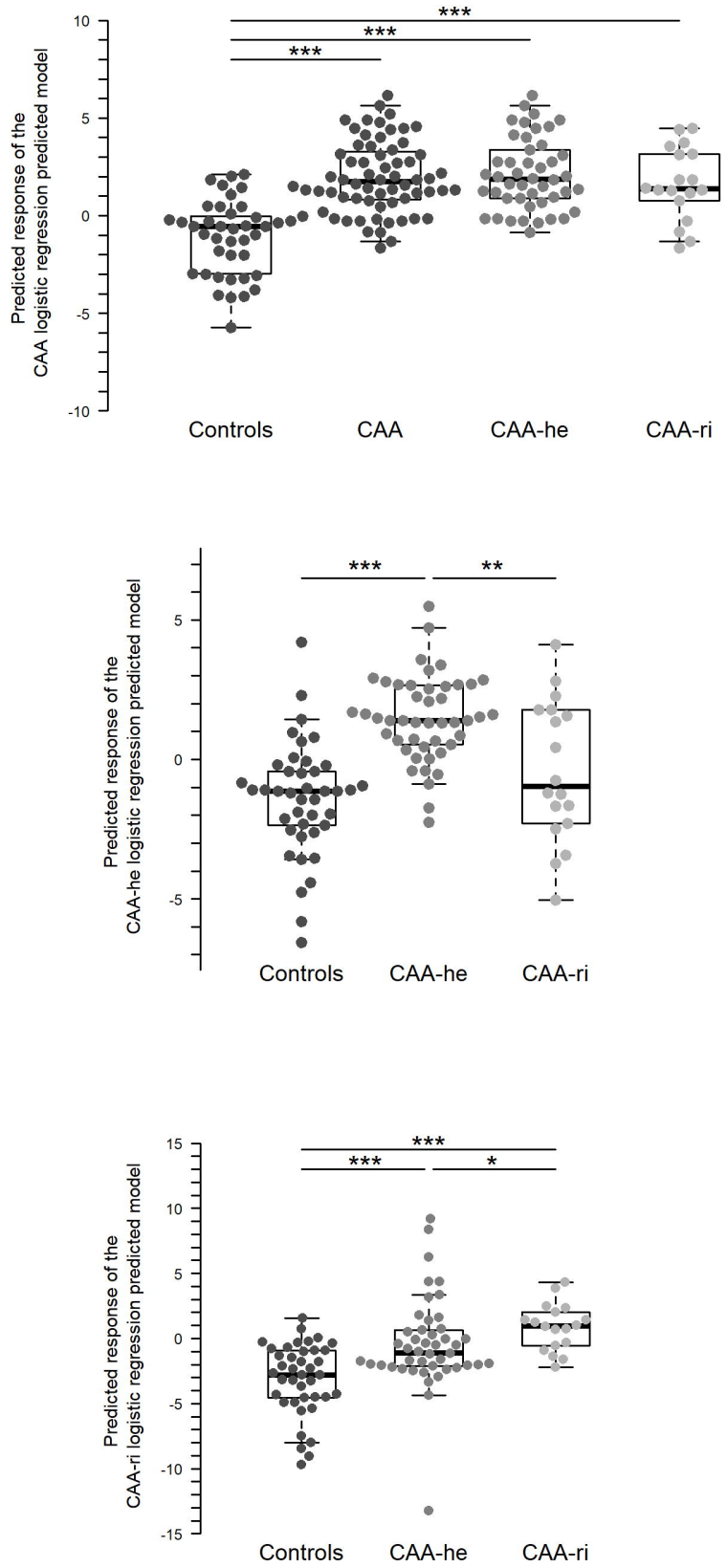